мере, напрямую, от государства; -проблемы волонтерства - это проблемы каждой конкретной личности, т.е. недостаточная личностная мотивация, а также представление о том, что для реализации своего потенциала необходимы какие-то особые условия в виде, например, «по-настоящему интересных творческих проектов».

В заключение отметим, что, с одной стороны, волонтерский опыт проекта вызвал широкий резонанс среди педагогического сообщества г. Ростова-на-Дону. С другой, что особенно ценно, участие в волонтерском движении выполняет особую роль в формировании профессиональных компетенций студентов, повышении их профессиональной деловой культуры.

Статья подготовлена в рамках реализации проекта № 18-1-002117 «Безопасные шаги во взрослую жизнь», победителя конкурса Президентских грантов 2018 г.

$* * *$

1. Киселева Татьяна Геннадьевна Мотивация и эрзац-мотивация волонтерской деятельности // Ярославский педагогический вестник. 2013. №4. URL: https://cyberleninka.ru/article/n/motivatsiya-ierzats-motivatsiya-volonterskoy-deyatelnosti (дата обращения: 14.05.2019).

2. Овруцкая Г.К. Интерактивные методы профилактики подростковой преступности // Новые направления и концепции в современной науке. Педагогические науки. Сборник научных трудов по материалам III Международной научно-практической конференции (25 марта 2019 года, г. Смоленск) / МНИЦ «Наукосфера». Смоленск, 2019. с. 7-9.

\title{
Тазетдинова Е.Н.
}

Разработка и реализация педагогической модели формирования гражданской идентичности обучающихся колледжа

ГАПОУ «Иркутский колледж экономики, сервиса и туризма» (Россия, Иркутск)

doi 10.18411/sciencepublic-04-07-2019-05

idsp sciencepublic-04-07-2019-05

В последние годы в России образовательный процесс осуществляется в явных противоречиях. С одной стороны, подготовка кадров осуществляется с идеологией открытого общества, такая позиция не порождает качеств гражданина, а с другой стороны, есть потребность в укоренении идей, способствующих объединению российского общества. Конкурентная профессиональная среда обязывает повысить требования не только к специальной подготовке выпускников образовательных организаций среднего профессионального образования, но и к уровню их общего развития, направленного на формирование гражданской идентичности.

Без формирования гражданской идентичности гражданское общество появиться не может[5]. Системе образования в вопросе формирования гражданской идентичности отводится особая роль.

Профессионализм кадрового состава является одним из решающих факторов повышения эффективности профессиональной деятельности. Не случайно Президентом Российской Федерации предлагается разработать научно обоснованные мероприятия, направленные на формирование высококвалифицированного и ответственного кадрового состава, способного по своим профессиональным, личным, деловым и морально-психологическим качествам эффективно выполнять возложенные задачи[2].

В требованиях к результатам освоения профессиональной образовательной программы, сказано, что выпускник, должен обладать общими и профессиональными компетенциями. Компетенции успешнее формируются, если обучающиеся обладают 
профессионально значимыми качествами личности [3]. Более того, Федеральные законы и Правительственные акты, регламентирующие профессиональную деятельность специалистов, устанавливают повышенные гражданские качества к личному составу, исполняющему волю государства. Выполнение этих требований обуславливает необходимость создания современной системы формирования гражданской идентичности обучающихся. Исходя из этого, актуальным является понимание всеми участниками образовательного процесса сущности содержания критериев и уровней сформированности гражданской идентичности относительно конкретной области профессиональной деятельности.

Проектируя педагогическую модель формирования гражданской идентичности будущего специалиста, категория профессиональной компетентности была рассмотрена с позиции личностного развития и образовательного результата.

Анализ нормативных актов и научной литературы позволил нам конкретизировать понятие «гражданская идентичность» как профессионально значимое качество личности будущего специалиста, выражающееся в наличии знаний прав и обязанностей граждан и их соблюдение, позволяющее эффективно владеть навыками гражданского поведения; отражающее его ценности и активную гражданскую позицию, приобретенное в процессе профессиональной подготовки. Для оценки сформированности гражданской идентичности обучающихся нами предложены следующее компоненты: когнитивный (знание личности о гражданских правах и обязанностях, формирующее правомерное поведение), ценностно-смысловой (признание и соблюдении прав и свобод человека и гражданина, толерантность, веротерпимость, уважение правовых основ государства); деятельностный (способность и желание гражданина проявлять активную гражданскую позицию); оценочный (осуществление самоанализа, самооценки); [4. с. 141-142].

В ГАПОУ «Иркутский колледж экономики, сервиса и туризма», на базе которого ведется работа над научно-исследовательской темой «Формирование гражданской идентичности обучающихся колледжа» проводился педагогический эксперимент. В состав экспериментальной и контрольной групп вошли обучающиеся по специальности «Право и организация социального обеспечения», близкие по всем выделенным признакам, стартовым условиям и результатам учебно-воспитательного процесса.

Проверка результативности разработанной педагогической модели и педагогических условий ее реализации осуществлялась в течение 2011-2018 г.г.

Формирующий этап эксперимента начинался с создания педагогических условий. Первое педагогическое условие: научно-методическое наполнение учебного материала содержанием гражданской направленности. Ведущая роль в формировании когнитивного компонента гражданской идентичности отводится дисциплинам профессионального учебного цикла. В ходе эксперимента разработаны: рабочие программы общепрофессиональных дисциплин и профессиональных модулей с ориентацией на формирование гражданской идентичности; фонды оценочных средств по общепрофессиональным дисциплинам и профессиональным модулям.

Второе педагогическое условие: проведение профориентационной работы, формирующей ценностно-смысловой компонент гражданской идентичности. В ходе эксперимента разработаны: программа профессиональных проб; программа дополнительного профессионального образования, предусматривающая стажировку на рабочих местах. При организации профориентационной работы применялись ресурсы участников сетевого взаимодействия, которыми являются: ГУФСИН России по Иркутской области, ГУМВД России по Иркутской области, Агентство по обеспечению деятельности мировых судей г. Иркутска.

Третье педагогическое условие: активное включение в волонтерскую деятельность направлено на формирование деятельностного компонента. На базе 
колледжа создан волонтерский отряд «Спасательный круг», практическая значимость которого заключается в проведении мероприятий, формирующих правомерное поведение среди студенческого сообщества.

На протяжении всего периода реализации педагогических условий формирования гражданской идентичности обучающихся, диагностировался оценочный компонент гражданской идентичности. Применяя Опросник ПлутчикаКеллермана-Конте «Индекс жизненного стиля» осуществлялась диагностика механизмов психологической защиты обучающихся, выявляя как ведущие, основные механизмы, так и оценивая степень напряженности каждого. Диагностика проводилась совместно с психологами колледжа и группы психологической защиты ГУФСИН России по Иркутской области. Диагностика проводилась 2 раза в семестр в течение периода обучения. На основе индивидуальных психологических особенностей личности обучающегося психологической службой проводились мероприятия с использованием индивидуальных и групповых форм работы: психологические тренинги, лекции, беседы и иные формы пропаганды психологических знаний.

Обработка результатов эксперимента осуществлялся с помощью $\mathrm{t}$ - критерия Стьюдента. Экспериментальным путем проверена результативность предложенных педагогических условий формирования гражданской идентичности обучающихся. Сравнительный анализ контрольной и экспериментальной групп показывает, что когнитивный компонент гражданской идентичности у обучающихся контрольной группы не достигает того же уровня, как у обучающихся экспериментальной группы. При проведении статистического анализа доказана гипотеза о различии данных контрольной группы и экспериментальной группы при $t_{\ni м п ~}=2.8$. Полученное эмпирическое значение $\mathrm{t}$ (2.8) находится в зоне значимости. Значения ценностносмыслового компонента у обучающихся контрольной и экспериментальной группы на завершающем этапе эксперимента находятся в зоне значимости при $\mathrm{t}_{\text {эмп }}=2,7$. У обучающихся стали более осмысленными представления о специфике гражданских прав и обязанностей. Более глубоким стало понимание функций гражданского общества. Применяемые психологические диагностики подтверждают сравнительную разницу уровней сформированности когнитивного, ценностно-смыслового, деятельностного компонентов гражданской идентичности между экспериментальной и контрольной группами. Диагностика оценочного критерия показала преобладающим в ЭГ и КГ конструктивного способа психологической защиты.

Итак, гражданская идентичность обучающихся не возникает, она формируется результате длительной, целенаправленной и специально организованной деятельности. Итоги экспериментальной работы по формированию гражданской идентичности показывают положительные результаты, через единство и взаимосвязь структурных и функциональных компонентов образовательной среды позволяющих повысить у обучающихся, мотивацию к профессиональному саморазвитию.

$$
\text { *** }
$$

1. Иванова, Н.Л. Гражданская идентичность как социальный капитал [Электронный ресурс] URL: http://uisrussia.msu (дата обращения 21.01.2018).

2. Официальный сайт Президента России. [Электронный ресурс] URL: http://www.kremlin.ru (дата обращения 11.10.2018)

3. Приказ Минобрнауки России от 12.05.2014 N 508 (ред. от 14.09.2016) «Об утверждении федерального государственного образовательного стандарта среднего профессионального образования по специальности 40.02.01 Право и организация социального обеспечения».

4. Тимошенко А. И., Тазетдинова Е.Н. Понятие гражданской идентичности и приемы ее формирования в средних профессиональных образовательных учреждениях //Профессиональное образование в России и за рубежом. 2016. №3 (23). С. 140-144.

5. Указ Президента Указ Президента РФ от 19.12.2012 N 1666 «О Стратегии государственной национальной политики Российской Федерации на период до 2025 года»// «Собрание законодательства РФ», 24.12.2012, N 52, ст. 7477. 